\title{
Spanish null complement anaphora at the grammar-discourse interface
}

\author{
L'anàfora de complement nul en espanyol \\ en la interfície gramàtica-discurs
}

\author{
Iker Zulaica-Hernández
}

Indiana University-Purdue University Indianapolis. izulaica@iupui.edu Received: 23/04/2018. Accepted: 07/08/2018

\begin{abstract}
The study of null complement anaphora (NCA) is important for the grammar-discourse interface as it seems to incarnate some of the core processes commonly found in other discourse phenomena, namely: reference, anaphora, ellipsis, inference, salience, or accommodation. Although NCA has been studied extensively, the debate whether it is an elliptical or an anaphoric process is still ongoing. This paper contributes to the view of NCA as a deep anaphor by providing evidence from Spanish discourse. I argue that NCA is an anaphor that selects the most prominent antecedent in well-defined discourse hierarchical structures. My analysis is mainly based on the comparison among Spanish neuter pronouns and NCA, and on the observed similar behavior shown by NCA and pronouns under discourse embedding conditions. Previous accounts on NCA are reviewed (Depiante 2000, 2001; Williamson 2012), and a tentative analysis of VP ellipsis based on discourse relations (Hardt \& Romero 2004) is applied to Spanish NCA.
\end{abstract}

Keywords: reference; null complement anaphora; ellipsis; discourse relations; NCA.

Resum: L'estudi de l'anàfora de complement nul (null complement anaphora, NCA, en anglès) és rellevant en l'estudi de la interfície gramàtica-discurs, atès que sembla materialitzar alguns dels processos centrals d'altres fenòmens com ara la referència, l'anàfora, l'el·lipsi, la inferència, la prominència o l'acomodació. Tot i que l'NCA ha estat estudiada a bastament, encara és viu el debat sobre si es tracta d'un procés ellíptic o anafòric. Aquest article contribueix a la consideració de l'NCA com una anàfora profunda a partir d'evidències discursives en espanyol. Defensem que l'NCA és una anàfora que selecciona l'antecedent més prominent en estructures discursives jeràrquiques ben definides. La nostra anàlisi es basa, principalment, en la comparació entre els pronoms neutres i l'NCA en espanyol, i en la similitud del comportament manifestat

\) Zulaica-Hernández, Iker. 2018. "Spanish Null Complement Anaphora at the Grammar-Discourse Interface”. Quaderns de Filologia: Estudis Lingüistics XXIII: 81-104. doi: 10.7203/qf.23.13522 
per l'NCA i els pronoms en condicions d'inserció discursiva. Revisem explicacions anteriors de l'NCA (Depiante 2000, 2001; Williamson 2012), i tractem d'aplicar a l'NCA en espanyol una proposta d'anàlisi de l'el-lipsi de SV basada en relacions discursives (Hardt \& Romero 2004).

Paraules clau: referència; anàfora de complement nul; el-lipsi; relacions discursives; NCA. 


\section{Introduction ${ }^{1}$}

Because elliptical and anaphoric processes take place across sentence and clause boundaries they are important for the grammar-discourse interface. Elliptical and anaphoric processes are also interesting for what they can tell us about discourse reconstruction mechanisms, and as general discourse cohesion/coherence strategies. Null Complement Anaphora (NCA, henceforth) occurs when the complement of some verbs (mainly modal and aspectual ones) is elided. Most commonly, the elided complement is an infinitive, but it can also be propositional. In (1), the elided complement of the modal 'debería' is glossed as NCA $(=$ traerlo).

(1) Me pide que lo traiga, pero no sé si debo NCA. to-me ask-he that it bring but not know-I if should-I 'He's asking me to bring it, but I don't know if I should.'

NCA seems to fall between these two general processes: ellipsis and anaphora, and this apparent dual nature has made the study of NCA a complex task. Also, the intrinsic anaphoric nature of ellipsis, and the fact that only a limited set of predicates allow NCA are additional obstacles toward a definite theory of null complement anaphora. Generally speaking, the elided material in an elliptical construction has to be recovered from the previous discourse via a matching antecedent. A case of VP ellipsis is shown in (2), where the elided material can be easily recovered from the antecedent VP (= 'tomó') in the first conjunct.

$$
\begin{aligned}
& \text { Pedro tomó un café y María } \varnothing \text { un refresco. } \\
& \text { Pedro had a coffee and Mary } \varnothing \text { a soda. } \\
& \text { 'Peter had some coffee, and Mary (had) a soda.' }
\end{aligned}
$$

There are two main structural approaches to the study of ellipsis. One approach analyzes all elliptical processes as a radical version of phonological reduction. This analysis assumes the existence of a syntactic unit that is phonetically empty. Thus, the empty set symbol $\varnothing$ in (2) above would stand for the verb 'tomó' without phonological infor-

\footnotetext{
${ }^{1}$ I want to thank two anonymous reviewers for their constructive and helpful comments. All remaining errors are mine.
} 
mation attached to it. This approach entails that the ellipsis site has full syntactic structure (and logical form, consequently). In (3), the gap or ellipsis site is the full VP 'le gusta leer novelas'.
A Juan le gusta leer novelas y a María $\emptyset$ también to Juan LE likes to-read novels and to María too
'John likes reading novels, and so does Mary.'

In the second approach, it is assumed that ellipsis is fundamentally an anaphoric phenomenon. Under the anaphoric analysis, the gap or ellipsis site is treated as a null pronoun, analogous to the null subject pronoun (personal pro) that we find in (4), and subject to analogous anaphor resolution processes as any other pro-forms. The gap in (4) would thus be treated as a silent pro-form: a pro-VP (see the seminal work by Back and Partee 1980; Hardt 1993 and Klein 1987 on the anaphoric approach to ellipsis.)

$$
\begin{array}{ll}
\varnothing \text { llegué a } & \text { tiempo. } \\
\text { I arrived on } & \text { time }
\end{array}
$$

The debate whether ellipsis is an anaphoric process or a syntactic process is still ongoing as there are strong arguments in favor of either analysis. But regardless of the approach to ellipsis chosen, it is widely acknowledged that the information that is deleted, or phonologically reduced, in ellipsis must be presupposed.

VP ellipsis and NCA illustrate the surface-deep anaphor distinction in Hankamer and Sag (1976), for whom NCA is a deep anaphor: a silent, elided or null pronoun. In short, deep anaphors do not require a linguistic antecedent, only some semantic content that may be provided by linguistic, or non-linguistic means. Furthermore, if the antecedent of a deep anaphor is linguistic then its syntactic form is not so narrowly constrained as with surface anaphora (ellipsis). Advocates of NCA as ellipsis argue in favor of an analysis for NCA as a subtype of VP ellipsis. However, NCA and VP ellipsis differ in some respects. For example, NCA does not require syntactic parallelism. In other words, the antecedent and the elided material do not need to be identical. Notice that the NCA in (5) can only be reinterpreted from the VP complement in the first conjunct as 'irse', but never as 'que se fuera'. 
(5) Le pedí a Juan que se fuera, pero no aceptó NCA. to-him asked-I to Juan that CL leave but not accepted-he 'I asked John to leave, but he didn't accept.'

Also, NCA allows for pragmatically controlled antecedents, which means that the antecedent of an NCA does not have to be overtly expressed, and the sentential or VP complement of the verb may simply be understood from context, as in (6). The material within curly brackets indicates phonetically null (unpronounced) material.

(6) [Seeing John as he struggles to complete a 2,000-piece puzzle]

No podrás \{hacerlo\}

not will be able to-you \{do-it\}

'You won't be able to do it.'

This paper is a contribution to the analysis of NCA in Spanish, a phenomenon largely ignored to date, in particular at the grammar-discourse interface. I argue in favor of a treatment of NCA as a deep anaphor. More precisely, I argue that Spanish NCAs operate as generic anaphors such that they have a wide range of antecedents which obey prominence discourse hierarchical structures. My claim is supported by evidence from three main sources: (i) NCA's behavior in the context of discourse relations. To that aim, I apply Hardt \& Romero's (2004) analysis of VP ellipsis based on discourse relations to Spanish NCA. The analysis shows that NCA patterns with pronouns referentially under the same discourse structural conditions. (ii) The observation that NCA shares important characteristics with Spanish neuter pronouns (this is the view proposed by Depiante $(2000,2001)$ for Spanish and Italian NCA). (iii) NCA as a definite expression; a more recent treatment by Williamson (2012) based on the different referring properties of pronouns and definite expressions. In all, the analysis presented in this paper shows that all the NCA cases analyzed in terms of phonological reduction correspond to prominence phenomena which the NCA as anaphor analysis can easily handle. As an anaphor, NCA would thus be resolved to the most prominent antecedent following standard pronoun resolution processes. From this claim it follows that no deletion mechanism is needed to explain NCA. 


\section{NCA as ellipsis}

As I said above, NCA can be looked upon as a case of ellipsis, that is, as an instance of surface anaphor having syntactic structure (see López, 1994, Sáez, 1990, among others). Superficially at least, NCA seems to share the most basic routines found in other elliptical phenomena: an antecedent expression; an ellipsis site; and the information that has been deleted can be recovered and must be presupposed. NCA, however, differs with VP ellipsis in at least two crucial structural aspects. In VP ellipsis, the verb cluster (lexical verb and auxiliary, if any) is always elided as in (7); whereas in NCA a verbal element (lexical or auxiliary) is always left stranded and all the material following it is elided, as in (8).

$\begin{array}{lllll}\text { María quiere leer, pero } & \text { yo } & \text { no } & \emptyset . \\ \text { María wants to-read but } & \text { I } & \text { not } & \\ \text { 'María wants to read, but I don't.' } & & & \end{array}$

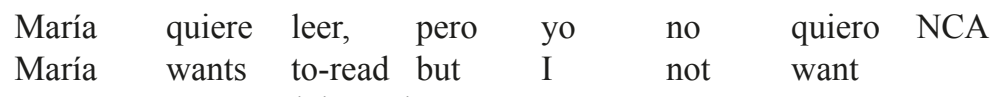

Perhaps the most convincing argument against a treatment of NCA as VP ellipsis is the impossibility of extraction from NCA, as shown in (9). In this example, the clitic pronoun 'la' in the second conjunct cannot be extracted from within the domain of the modal verb 'debería'. This seems to be an indication that NCA does not have syntactic structure, hence it must be an elided or null pronoun instead.

$$
\begin{aligned}
& \text { *Juan la quiere ver, y Pedro también la debería NCA. } \\
& \text { Juan it want-he to-see and Pedro too it should-he } \\
& \text { 'Juan wants to see it, and Pedro should, too.' }
\end{aligned}
$$

With these obstacles in mind, advocates of NCA as an elliptical process could be more tempted to view it as a subtype of VP ellipsis. In the next section, I tentatively apply a theory of ellipsis based on focus and discourse relations to Spanish NCA in order to add additional evidence in favor or against a treatment of NCA as an elliptical process. This 
theory has already been successfully applied to the interpretation of VP ellipsis and Sluicing ${ }^{2}$.

\subsection{NCA as a subtype of VP ellipsis in the context of discourse relations}

Textual coherence relations have been applied to the study of ellipsis. Kehler $(2000,2002)$ argues that VP ellipsis depends on three specific discourse coherence relations among the clauses involved: resemblance, contiguity and cause-effect relations. Resemblance (or parallel) is based on the similarity or dissimilarity between events or entities. Cause-effect relations instantiate implicational relations as pointed out by Kehler (2000: 541): "Infer P from the assertion of S0, and Q from the assertion of S1, where normally $\mathrm{P} \rightarrow \mathrm{Q}$." An example of a cause-effect relation is the one that can be inferred from the clauses in (10) [example from Kehler 2002].

(10) This problem was to have been looked into, but obviously nobody did. [look into the problem]

It is important to note that for Kehler discourse relations are also key in resolving anaphors. Thus, certain discourse connectives generally indicate a particular discourse relation among the utterances involved. For example, the presuppositional connective 'too' is a common marker of the resemblance (parallel) relation indicating that the propositional arguments of the relation are related by similarity. Likewise, connectives such as 'but', 'because', 'even though' would mark different cause-effect implicational relations such as contrast, explanation, etc.

Kehler does not underestimate the role that syntax plays in ellipsis; however, his theory makes a clear distinction between syntactic vs. semantic (discourse based) ellipsis. In his theory, certain discourse relations, such as cause-effect ones, occur at the propositional level. When this happens, the ellipsis is no longer syntactically sensitive since

\footnotetext{
${ }^{2}$ Sluicing is an elliptical process whereby the ellided material is larger than the VP projection, and leaves behind a wh-word having an NP or implicit element as antecedent. An example of sluicing is given in (i).

(i) Alguien me lo contó, pero no recuerdo quién $\varnothing$.

'Someone told me, but I can't remember who.'
} 
no reconstruction is needed to interpret the coherence discourse relation. Conversely, certain discourse relations (i.e. resemblance/parallel) can only be established by using sub-clausal constituents. When resemblance is involved, the arguments of the relation are to be reconstructed, and syntactic conditions must be obeyed. Although Kehler's theory has found some empirical support, recent empirical work (Frazier and Clifton (2006)) has shown that parallelism is generally preferred for all coherence relation, thus raising questions about the empirical basis for coherence theory.

Kehler's theory is not the only discourse-based approach to VP ellipsis though. Hardt and Romero (2004) develop an analysis of the parallelism requirement of ellipsis based on discourse structure. More precisely, they argue that a matching antecedent clause must be found in the discourse tree, and that such antecedent clause must locally c-command the clause containing the ellipsis site. Although their theory is focused on VP ellipsis and sluicing phenomena, I think their analysis can be tentatively applied to NCA in order to determine whether NCA shares discourse structural properties with other elliptical phenomena or, should be given an anaphoric treatment instead. In what follows, I will apply Romero and Hardt's analysis of VP ellipsis to Spanish null complement anaphora.

Hardt and Romero work under two main assumptions, namely: 1) that ellipsis and other reduction processes require at least a certain level of parallelism (a matching relation) between the antecedent clause and the reduced clause; 2 ) that discourse structure is relevant to the interpretation and resolution of ellipsis (and anaphor resolution, too) (2004: 1). Similarly to Kehler's proposal, their theory entails a set of discourse relations among the utterances in discourse that are explicitly signaled via discourse particles. They also assume, as it is standard practice in the literature of discourse relations, that these relations can be graphically represented with tree structures. They use the following discourse relations:

Temporal:

Cause-effect/subordination:

Concessive:

Parallel:

Contrast:

Consequence:
A before/after B

A because $B$

A although $B$

$\mathrm{A}$ and $\mathrm{B}$ too

A but not $\mathrm{B}$

A so B; A thus B 
Question/Answer:

Constructions:
A? B

If $\mathrm{A}$ then $\mathrm{B}$; forall $\mathrm{AB}$; most $\mathrm{AB}$; etc.

In dealing with ellipsis, the matching relation between the ellipsis site and ellipsis antecedent is defined as a condition (2004: 4):

\section{Matching condition}

Take an ellipsis site $e$ with an ellipsis antecedent $a$ in the discourse. Ellipsis requires that there be some phrase $E$ containing the ellipsis $e$ and some phrase $A$ containing the ellipsis antecedent $a$ such that $\llbracket A \rrbracket$ is, or contextually implies, a member of $F(E)$.

Hardt and Romero's proposal adopt Rooth's (1992a) formalization of the focus value of an expression that he developed in his theory of focus interpretation and ellipsis. Thus, $\mathrm{F}(\mathrm{E})$, or the focus semantic value of the clause $E$ in the matching condition above, corresponds to the set of propositions in which the focus material is replaced with some appropriate contextually salient alternative of the same semantic type. The focus semantic value (the $p$-set in Rooth's 1985) of (12), with focus on the subject JOHN, is the set of propositions of type [ $x$ attended the meeting], where $x$ is to be replaced with a salient individual (of type $e$ ).

(12) JOHN attended the meeting.

(13) Focus semantic value of (12): $\left\{\mathrm{p} \mid \exists x \in \mathrm{D}_{\mathrm{e}}[\mathrm{p}=\mathrm{x}\right.$ attended the meeting]\}, where $\mathrm{D}_{\mathrm{e}}$ indicates that the focused material is to be replaced with an element of type $e$.

The formula in (13) would correspond to the set of propositional alternatives: Mary attended the meeting; George attended the meeting; Lisa attended the meeting, etc.\} We now have the tools needed to apply Hardt and Romero's analysis to NCA cases in order to check whether a treatment of NCA as VP ellipsis based on discourse relations is feasible. In (14), the ellipsis site is the infinitival complement of the second clause, represented with the symbol $e$. The antecedent is the infinitival complement of the first clause [descansar]. Following their analysis, the ellipsis would be licensed since the proposition denoted by the first clause is a member of the focus semantic value of [PEDRO quiere descansar], that is, [María quiere descansar $]_{\mathrm{S} 1} \in \mathrm{F}([\mathrm{PEDRO}$ quiere descan$\left.\mathrm{sar}]_{\mathrm{S} 2}\right)$. 
(14) $[\text { María quiere descansar }]_{\mathrm{S} 1}$ y [PEDRO también quiere $\left.e\right]_{\mathrm{S} 2}$. 'Mary wants to rest, and Pedro does, too.'

An example of English VP ellipsis (translated from Hardt and Romero and applied to Spanish) is shown in (15). Note that only the VP of S1 (llegó después de que María cenara), but not the VP (cenara) in the embedded clause $\mathrm{S} 3$, can be the antecedent of the ellipsis site in S2.

(15) [Juan llegó después de que [María cenara $\left.]_{\mathrm{S} 3}\right]_{\mathrm{S} 1}$, pero [Pedro no *(cenó)/ (llegó después de que María cenara) $]_{\mathrm{S} 2}$

'John arrived after Mary had diner, but Peter didn't.'

The discourse tree in Figure 1 shows two discourse relations: a Contrast relation among S1 and S2 marked by the particle 'pero', and a Temporal relation among S1 and S3 marked by the particle 'después'.

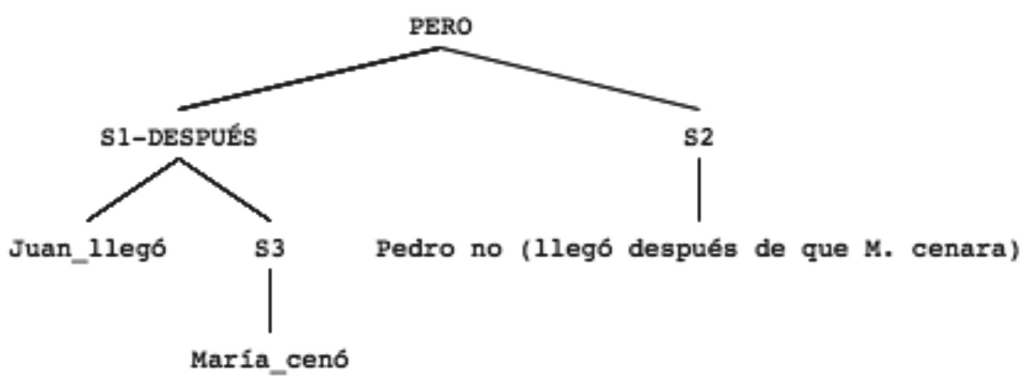

Figure 1. Tree for discourse (15)

Hardt \& Romero explain the impossibility for the ellipsis site to be resolved to the VP in S3 because S3 does not c-command S2; where c-command and local c-command are defined as follows (2004: 2)

- Standard C-command:

A c-commands B iff every node dominating A also dominates B.

- Local C-command:

A locally c-commands B iff A c-commands B and there is no $\mathrm{C}$ c-commanding $\mathrm{B}$ that appears between $\mathrm{A}$ and $\mathrm{B}$. 
A similar analysis and explanation can be applied to the NCA in (16). Note that only the NCA with 'quiso' in S2, but not the one with 'pudo', is the only possible outcome available in this sentence. In other words, the NCA can only be resolved to the complement antecedent in $\mathrm{S} 1$ (cenar antes de que M. llegara), and not to the embedded complement (llegar) in S3.

(16) [Juan quiso cenar antes de que [María pudiera llegar $\left.]_{\mathrm{S} 3}\right]_{\mathrm{S} 1}$, pero [Pedro no quiso $\mathrm{NCA} /{ }^{*}$ sí pudo $\left.\mathrm{NCA}\right]_{\mathrm{S} 2}$.

'John wanted to dine before Mary could arrive, but Peter didn't want to/ couldn't.'

Like VP ellipsis, NCA also appears to be sensitive to discourse structure and c-command conditions as shown in Figure 2. The tree shows that NCA cannot be resolved to the complement antecedent in S3 because S3 does not c-command S2.

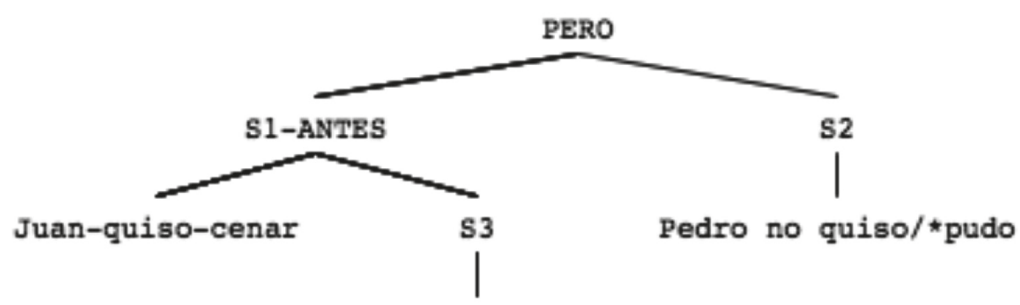

María pudo llegar

Figure 2. Tree for discourse (16)

In principle, it seems that changing the discourse relations among the utterances in the discourse does not alter the structural licensing conditions for NCA. In (17), we have a Parallel relation among S1 and S2 marked by the 'y...también' conjunction, and a Concession relation among S1 and S3 explicitly marked by the concessive connective 'aunque'. Again, the NCA can only be resolved to the infinitival complement of the matrix verb in S1 (ver la película). Resolving the NCA 
with 'debe' in S2 to the complement (estudiar) gives an ungrammatical result ${ }^{3}$.

(17) [Juan quiere ver la película aunque [María deba estudiar $\left.]_{\mathrm{S} 3}\right]_{\mathrm{S} 1}$, y [Pedro también quiere/*debe $\mathrm{NCA}]_{\mathrm{S} 2}$.

'Although María needs to study, Juan wants to see the movie, and Pedro needs to/wants, too.'

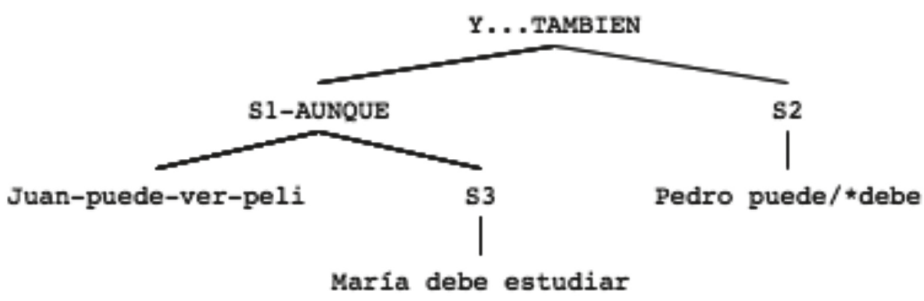

Figure 3. Tree for discourse (17)

The impossibility to resolve NCA under certain discourse structural conditions adds evidence in support of the analysis of NCA as an elliptical process (most likely as a subtype of VP ellipsis), and against a view of NCA as an anaphor. However, this conclusion is not warranted since pronouns present a similar behavior under similar discourse structural conditions. Consider (18), with discourse relations Parallel (S1, S2) and Temporal (S1, S3). It seems that the pronoun in S2 can only be resolved to the NP 'las gambas' in S1, but not to the NP 'las almejas' in the embedded clause S3.

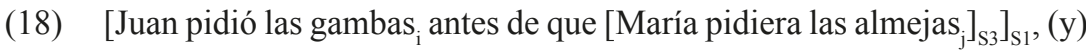
[Pedro también $\operatorname{las}_{\{i / * j\}}$ pidió $]_{\mathrm{S} 2}$.

'John ordered the shrimp before Mary ordered the clams, and Pedro ordered them, too.'

If this observation is correct then NCA would share with pronouns their inability to corefer with an NP in a subordinate clause that enters in a discourse-structural temporal relation with a matrix clause. However,

\footnotetext{
${ }^{3}$ It seems to me that this possibility improves when the verb is changed to the conditional form 'debería' in S3 and S2.
} 


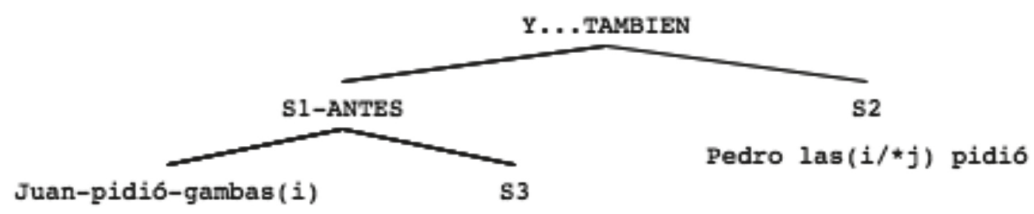

Maria pidi6 almejas(j)

Figure 4. Tree for discourse (18)

when the discourse structure is changed as in (19) to include a Contrast relation among S1 and S3 -a relation marked by the particle 'pero'- and a Parallel relation among S1 and S2, the pronoun becomes ambiguous and may be resolved to either NP argument. Note that the verb form of S3 in (19) is exactly the same verb form as in S2 (compare with the use of a subjunctive form in $\mathrm{S} 3$ and a preterite in $\mathrm{S} 2$ of (18)). This might be an indication that verb tense/mood matters when it comes to resolving pronouns in Parallel discourse configurations. In other words, it may well be that Parallel configurations, marked by conjunctions such as ' $y$... también', impose stiff structural similarity among the parallel structures (clause A and clause B), and that such strong similarity also constraints the resolution of anaphors within Parallel relations. In other words, the pronoun in VP2 can only be resolved to an argument in VP3 if and only if VP2 and VP3 share 'identical' structures, including verb tense/mood.

(19) [Juan pidió las gambas ${ }_{\mathrm{i}}$ pero [María pidió las almejas $\left.]_{\mathrm{S} 3}\right]_{\mathrm{S} 1}$, (y) [Pedro también las ${ }_{\{i j\}}$ pidió $]_{\mathrm{S} 2}$.

'John ordered the shrimp but Mary ordered the clams, and Pedro ordered them, too.'

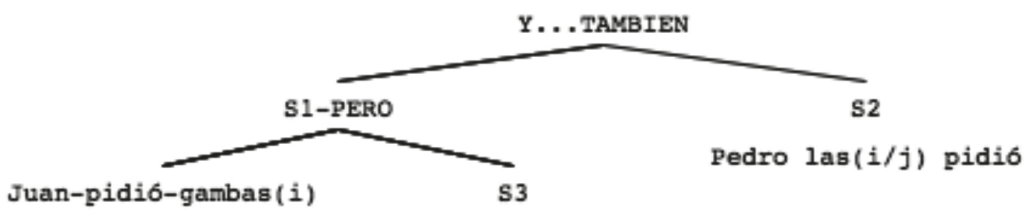

Maria pidi6 almejas(j)

Figure 5. Tree for discourse (19) 
Another explanation for the differing referential behavior of the pronoun in (18) and (19) is concerned with the level of structural embedding of the antecedent. Thus, the pronoun in (18) cannot be resolved as 'las almejas' because this NP is the internal argument of a subordinate VP. The word 'aunque' in this case would be a subordinating conjunction, and the CP node would act as a barrier or island for referential purposes. Note that the same ungrammatical result is obtained when VP ellipsis is involved, as in (20). In this example, the VP proform ' 10 hizo' can only refer to the whole VP that includes the matrix verb plus the subordinate clause (VP1). The same applies if we assume total phonological reduction.

(20) Juan [ ${ }_{\mathrm{VP} 1}$ pidió las gambas antes de que [ $\mathrm{VP}_{\mathrm{VP}}$ María pidiera las almejas]], y Pedro también $(\varnothing / \text { lo hizo })_{\{\mathrm{VP} 1 / * \mathrm{VP} 2\}}$

'John ordered the shrimp before Mary ordered the clams, and Pedro ordered them, too.'

Conversely, both the pronoun and VP ellipsis are licensed when no embedding is present and the S1 and S2 utterances are coordinated with the conjunction 'pero'. In a coordinated structure, no referential barrier is present hence the pronoun 'las' and the VP ellipsis are ambiguous. The level of syntactic embedding can be transferred to discourse structural embedding as shown in (18). Thus, for example, it has been shown (Polanyi, 1988; Asher \& Vieu, 2005) that coordinating and subordinating discourse relations play a different role in structuring discourse and in anaphora resolution.

The comparative analysis of NCA and VP ellipsis presented in this section is no more than a preliminary sketch. A detailed analysis of the subordinating or coordinating nature of the Parallel, Contrast, Temporal or Concession relations is beyond the purposes of this paper. However, we have seen that NCA patterns with pro-forms at least in one important characteristic; that is, NCA and pro-forms share their inability to corefer with an antecedent in a clause that enters in a discourse-structural subordinating relation with a matrix clause. This is, in my view, a clear indication in favor of treating NCA as a pro-form. In the next sections, I will provide further evidence in favor of treating NCA as a deep anaphor based on striking similarities between NCA and neuter pronouns. 


\section{NCA as a pro-form}

As I mentioned in the introduction to this paper, null complement anaphora-along with other elliptical or elliptical-like structures such as fragments or sloppy identity readings-poses a problem for unitary analyses of ellipsis solely based on copy and phonological deletion mechanisms. NCA requires, in most cases, an interpretive process in which the linguistic antecedent is accommodated. In her investigation of NCA in Spanish and Italian, Depiante $(2000,2001)$ supports the deep anaphora diagnosis for NCA. She proposes a treatment of NCA as a free variable of semantic types $\langle s,\langle e, t\rangle\rangle$ (for properties), $\langle s, t\rangle$ (for propositions), $\langle\langle s$, $t\rangle, t\rangle$ (for questions) depending on the type of predicate that selects the NCA. Crucially, NCA can never be of type $\langle\mathrm{e}\rangle$ (for individuals). For this author, NCA is a null pro-form, the null counterpart of English 'it', or Spanish 'lo'. As she points out: 'In all respects, NCA behaves like a null sentential/clausal pro-form. Sentential pro-forms such as 'it' behave like pronouns in all respects. They are deep anaphors." (2000: 74).

In a recent paper (2018), I investigate the anaphoric possibilities of Spanish NCA within the broader context of the Spanish neuter pronominal system. In this analysis, I propose that neuter pronouns can never denote individuals; they can only denote higher types such as propositions, properties, or sets of properties. Typical uses of neuter pronouns are shown in (21), where the different pro-forms (null-pro, eso, lo) corefer with the proposition denoted by A's utterance.

A: Juan ha rechazado el premio.

John has rejected the prize

'John rejected the prize.'

B': null-pro es increíble.

it is unbelievable

'It/that is unbelievable.'

B": ¿Quién te ha dicho eso?

Who to-you has said that

'Who told you that?'

B"”: ¡No me lo puedo creer!

Not ME it I-can to-believe

'I can't believe it/that!' 
The possibility for neuter demonstratives to denote/refer to individuals (type e) is only apparent. In (22), the speaker uses a neuter pronoun (instead of the feminine pronoun 'esa') to refer to the shirt 'camisa' lying on the floor with the purpose of presenting the entity denoted as a property or set of properties, not as an individual. The motivation behind this use is still unclear, but I argue that it is likely linked with the conveyance of emotional meanings or, more generally, with the speaker's attitude towards the entity referred to. In this line, neuter pronouns could be conceived of as type shifting devices that raise the type of the entity referred to; for example, from $\langle e\rangle$ (individuals) to $\langle e, t\rangle$ (properties) in (22).

(22) [looking at a shirt that someone left on the floor]

¿Qué hace eso en el suelo?

what does that-neut. on the floor

Why is that on the floor?

Crucially, NCA appears to share denotational possibilities with other Spanish neuter pro-forms, which seems to confirm Depiante's hypothesis that NCA can be considered a null neuter pro-form. The possible values of the NCA free variable are illustrated with examples (23)-(25). In (23), the NCA pro-form takes a set of properties as its denotation, a question in (24), and a proposition in (25). The NCA in these examples would be reinterpreted as: [ganar], [quién aprobó el examen], [que vayamos a Florida de vacaciones], respectively ${ }^{4}$.

El equipo intentó ganar pero no pudo NCA.

the team tried to-win but not be-able.to-PAST

'The team tried to win but they weren't able to (win).'
A: ¿Sabes quién aprobó el examen?
know-you who passed the exam
'Do you know who passed the exam?'
B: No $\{10 / \mathrm{NCA}\}$ sé.
not $\{$ it-neut./NCA $\}$ know-I
'I don't know.'

\footnotetext{
${ }^{4}$ It may be argued that the NCA in (25) is reinterpreted as an infinitive [ir de vacaciones], instead of taking the propositional complement. In my view, the two readings are possible.
} 
(25) María quiere que vayamos a Florida de vacaciones, Mary want-she that go-we-SUBJ. to Florida of vacations pero yo no quiero NCA.

but I not want-I

'Mary wants to go to Florida on vacation, but I don't want to.'

As we have seen, NCA pro-forms and neuter pronouns can equally corefer with a range of clausal antecedents, including questions as complements of certain predicates. Interestingly, as noted by Depiante, NCA can never denote individuals; an important denotational characteristic that, I claim, NCA shares with neuter pronouns, too. Examples (26) and (27) illustrate this observation.

María empezó a escribir, y Luis también empezó NCA. María began to write and Luis too started 'María began writing, and Luis (did), too.'

(27) *María empezó el libro, y Luis también empezó NCA. María began the book, and Luis too began 'María began the book, and Luis (did) too.'

The lexical semantics of the predicate and its selection properties matter since not any predicate can select NCA. Bosque (1984) and Brucart (1999) have identified several classes of predicates that allow NCA. Brucart, for example, observed an incompatibility between the neuter pronoun $l o$ and NCA whereby, generally, predicates that select lo do not tolerate NCA, and vice versa; an incompatibility also attested in English. In (28), the anaphoric use of the neuter pronoun coreferring with the infinitival complement is ungrammatical.

Juan intentó evitar el choque pero no $\left\{{ }^{*} 10\right\}$ pudo NCA. Juan tried to-avoid the crash but not $\{*$ it $\}$ was able to-he 'John tried to avoid the crash, but he couldn't.'

I also argue that NCA pronouns can also refer to groups of propositions and events. Consider (29), where the phonetically null proform can refer to the group of propositions introduced with the first two clauses. In this case, the NCA pro-form would be reinterpreted or reconstructed as 'se negó (a regar las plantas y coger el correo)'. 
(29) Le pedí a Juan que regara las plantas y

LE asked-I to John that watered the plants and

que cogiera el correo durante mi viaje, pero se negó

NCA.

that picked the mail, during my trip but SE refused-he

'I asked John to water my plants and pick my mail during my trip, but she refused.'

Neuter pronouns can also corefer with groups of events or propositions. Compare, for example, the use of the NCA pro-form above with the discourse anaphoric use of the neuter existential pronoun nada in (30).

(30) Le pedí a Juan que regara las plantas y

LE asked-I to John that watered the plants and

que cogiera el correo durante mi viaje. Nada que no

that picked the mail, during my trip. nothing that not

hubiera hecho antes.

have-SUBJ. done before

'I asked John to water my plants and pick my mail during my trip.

Nothing he haven't done before.'

Finally, another parallelism between NCA and neuter pronouns is their ability to restructure clausal antecedents. In other words, strict syntactic parallelism is not required for a felicitous use of NCA and neuter pronouns; i.e. the linguistic antecedent does not have to be identical to what it is actually recovered by the pronoun. In (31), the reference of the pronoun stems from the explicit linguistic antecedent but it cannot be identical, and the propositional antecedent 'que alguien lo explicara' is restructured as the preterite form 'explicó'. In (32), the linguistic antecedent is a passive form 'ser vacunado' (to be vaccinated) but the NCA has to be reinterpreted as 'vacunarlo' (vaccinate it).

(31) Era necesario que alguien lo explicara, y Juan lo hizo. was-it necessary that someone it-neut. explain and John it-neut. did 'Someone had to explain that, and Juan did (it).'

(32) Este perro debe ser vacunado, aunque su dueño no quiera NCA. this dog must be vaccinated, although its owner not want-he 'Although its master doesn't want to, this dog must be vaccinated.' 
Depiante's proposal on the semantics and referential behavior of NCA is compatible with a proposal that treats all Spanish neuter pronouns as definite expressions denoting a free variable that picks up its referent from the linguistic or extralinguistic context. It is also compatible with a view of neuter pronouns as elements that cannot denote individuals, but entities of higher types. NCA and neuter pronouns also share their ability to restructure antecedents, and corefer with groups of events and propositions. However, all this does not mean that NCA and neuter pronouns are exactly parallel in their referential properties, or that they have the same distributions.

At this point, I will draw an important conclusion regarding the status of NCA; that is, all surface anaphora issues can be predicted from deep anaphora. We have seen that NCA and pronouns share their inability to pick out referents embedded in subordinate clauses because these referents are always dominated by more prominent elements in the discourse. The embedding can be modeled in purely syntactic terms (clausal embedding at the point of a CP node) or in discourse-structural terms (as a subordinating relation). The notion of c-command is only a way to formalize prominence relations in discourse, but other formalizations are possible as in, for example, RST (Mann and Thompson 1988) or SDRT (Asher and Lascarides 2003). In all cases, NCA selects the most prominent element via anaphora and no syntactic deletion mechanism is needed.

Conversely, not all cases of deep anaphora can be accounted for by the deletion analysis. Take for example the cases of restructured antecedents that the VP ellipsis analysis cannot handle via syntactic deletion, as in (32) or (33).

Le pedí a Juan que se fuera, pero no aceptó

$(\mathrm{NCA} / *$ que se fuera).

'I asked John to leave, but he refused.'

Furthermore, NCA and neuter pronouns share clear parallelisms in their capacity to operate as anaphors.

\section{NCA as a definite expression}

A more recent alternative to the 'NCA-as-anaphor' view is the one by Williams (2012), who follows previous work on the same line 
a. Todo hombre que puso fichas en el 17 ganó NCA.

b. Todo hombre que puso fichas en el 17 ganó la/su apuesta.

c. \# Todo hombre que puso fichas en el 17 la ganó.

'Every man who put chips on 17 won $\{\mathrm{NCA} /$ the/his bet/\#it $\}$.'

Although the view of NCA as a definite expression is appealing there is, in my view, an important obstacle that makes this treatment questionable. As Williamson points out, NCA cannot introduce discourse referents for subsequent pronominal reference, whereas definite expressions can. This is shown in (38), where the pronoun in the second sentence cannot refer to the implicit argument introduced by the NCA in the first sentence 'the bet'. If NCA were a definite description, then subsequent pronominal reference should be possible . $^{5}$
Lee puso fichas en el 17 y ganó
$\operatorname{NCA}(=$ the bet $)$.
Lee put chips on the 17 and won
\# Desgraciadamente, eso significa que Juan la perdió.
Unfortunately that means that John it lost
'Lee put chips on the 17, and won. Unfortunately that means John lost it.'

In my view, this obstacle has more to do with the cognitive status of the type of argument allegedly introduced by the NCA than with NCA itself. In his study, Williams extends NCA to include implicit arguments that had not been considered in previous NCA accounts. It may well be the case that inferred antecedents, or inferrables in Prince's (1981) terminology, do not license NCA. Compare (38) with (39), a typical case of NCA with a pronoun in a subsequent sentence picking out the same antecedent as the NCA. Note that when the NCA does not have to be inferred because its antecedent is overtly expressed in the previous discourse, subsequent reference with a pronoun is $\mathrm{OK}$.

\footnotetext{
${ }^{5}$ For many authors, pronouns are definite descriptions. Under this view, pronouns and 'ordinary' definite descriptions would differ in that the former would be definite descriptions with an unresolved condition such as 'the $\mathrm{x}$ ' that will be resolved anaphorically in context.
} 
El equipo intentó ganar pero no pudo NCA (= ganar). the team tried to-win but was-not-able Sin embargo, lo consiguió a la semana siguiente. however it got to the week following 'The team tried to win, but they weren't able to (win). They did the following week, though.'

Williamson offers compelling arguments in favor of treating NCA as a definite description instead of a pronoun. Limitations of space prevent me from including most of these arguments though. In short, Williamson's main argument is that NCA should be considered as a definite description that depends on a series of restrictions in order to be resolved. Among those restrictions he includes the lexical semantics of the predicate selecting NCA, and general pragmatic factors in reference resolution. Importantly, Williamson notices that NCA patterns with definite descriptions, not pronouns, in being more sensitive to those factors.

\section{Conclusions}

NCA is worth investigating as a process that contributes to overall cohesion of discourse. Although the debate whether null complement anaphora is merely a structural process (ellipsis) or a referential one (anaphora) is still open, the view of NCA as an anaphor is the most widely accepted conceptualization of NCA today. In this paper, I have contributed to this view by providing evidence from Spanish NCA.

It is well known that different phenomena at the grammar-discourse interface have been given adequate explanations based on discourse structural constraints; anaphora resolution being a case in point. In discussing NCA within the scope of discourse relations, we have seen that NCA shares similarities with other pro-forms. In close resemblance with pronouns, I have shown that clausal embedding is a barrier for NCA interpretation and that discourse prominence may be a better predictor for NCA interpretability. Whether discourse prominence is modeled as traditional c-command or in terms of coordinating/subordinating discourse relations is irrelevant for a proper analysis of NCA.

Another revealing piece of evidence in favor of NCA as a deep anaphor comes from the observation that NCA shares core denotational properties with neuter pronouns. The analysis of Spanish NCA presented in this paper adds additional evidence to Depiante's proposal that NCA 
behaves as a null anaphor akin to propositional Spanish 'lo' or English 'it'. As an anaphor that corefers with clausal antecedents, NCA shares discourse anaphoric properties with neuter pronouns such as weak and strong neuter pronouns 'lo' and 'ello', and with neuter demonstratives. In this line, NCA would also share with other Spanish neuter pronouns its capacity to refer to higher-order entities such as propositions and events, but not to individuals (entities of type e). Furthermore, NCA also shares with neuter pronouns the ability to restructure antecedents.

An alternative approach to the traditional 'NCA is a pronoun' view extends the referential possibilities of NCA to include arguments of verbs beyond the clausal level. Under this approach, implicit NP arguments would also license the use of NCA, which would be more favorably viewed as a definite expression that receives the same interpretation in every context than as a pronoun (or a free variable). Although this conceptualization of NCA is compelling and poses interesting questions it presents some challenges, too. Perhaps, a serious obstacle to this hypothesis is the impossibility for NCA to introduce discourse referents that can be subsequently referred to via pronouns, which challenges the view of NCA as a definite expression.

\section{References}

Asher, Nicholas \& Alex Lascarides. 2003. Logics of Conversation. Cambridge: Cambridge University Press.

Asher, Nicholas \& Vieu, Laure. 2005. Subordinating and coordinating discourse relations. Lingua 115: 591-610.

Bosque, Ignacio. 1984. Negación y elipsis. Estudios de Lingüística 2: 171-199.

Brucart, José María. 1999. La Elipsis. In Bosque, Ignacio \& Demonte, Violeta (ed.) Gramática Descriptiva de la Lengua Española. Madrid: EspasaCalpe.

Clifton, Charles \& Frazier, Lynn. 2010. Imperfect ellipsis: Antecedents beyond syntax? Syntax 13(4): 279-297.

Condoravdi, Cleo \& Gawron, Jean Marc. 1996. The context-dependency of implicit arguments. In Kanazawa, Makoto; Pinon, Christopher \& de Swart, Henriëtte (ed.) Quantifiers, Deduction, and Context. Stanford, CA: CSLI Publications, 1-32.

Depiante, Marcela A. 2000. The syntax of deep and surface anaphora: A study of null complement anaphora and stripping/bare argument ellipsis. $\mathrm{Ph} . \mathrm{D}$. dissertation, University of Connecticut at Storrs. 
Depiante, Marcela A. 2001. On null complement anaphora in Spanish and Italian. Probus 13: 193-221.

Frazier, Lyn \& Clifton, Charles. 2005. The syntax-discourse divide: Processing ellipsis. Syntax 8(2): 121-174.

Frazier, Lyn \& Clifton, Charles. 2006. Ellipsis and discourse coherence. Linguistics and Philosophy 29(3): 315-346.

Gawker, Christopher. 2012. What is Tipper ready for? A semantics for incomplete predicates. Noûs 46(1): 65-81.

Hankamer, Jorge \& Sag, Ivan. 1976. Deep and surface anaphora. Linguistic Inquiry 7: 391-426.

Hardt, Daniel \& Romero, Maribel. 2004. Ellipsis and the structure of discourse. Journal of Semantics 21(4): 375-414.

Kehler, Andrew. 2000. Coherence and the resolution of ellipsis. Linguistics and Philosophy 23(6): 533-575.

Kehler, Andrew. 2002. Coherence, Reference and the Theory of Grammar. Stanford: CSLI Publications.

López, Luis. 1994. The syntactic licensing of VP ellipsis: A comparative study of English and Spanish. In Mazzola, M. (ed.) Issues and Theory in Romance Languages. Washington DC: Georgetown University Press, 333-354.

Mann, William C. \& Thompson, Sandra A. 1988. Rhetorical structure theory: Toward a functional theory of text organization. Text 8(3): 243-281.

Polanyi, L. 1988. A formal model of the structure of discourse. Journal of Pragmatics 12: 601-638.

Prince, Ellen F. 1981. Towards a taxonomy of given-new information. In Cole, Peter (ed.) Radical Pragmatics. New York: Academic Press.

Rooth, Mats. 1985. Association with Focus. PhD dissertation. University of Massachusetts, Amherst.

Rooth, Mats. 1992. Ellipsis redundancy and reduction redundancy. In Proceedings of the Stuttgart Ellipsis Workshop. Stuttgart, Germany.

Sáez, Luis. 1990. Antecedent-contained deletion and modals in Spanish comparative constructions. The Linguistic Review 6: 195-225.

Webber, Bonnie et al. 1994. Anaphora and discourse structure. Computational Linguistics 16(1).

Williams, Alexander. 2012. Null complement anaphors as definite descriptions. Proceedings of SALT 22: 125-145.

Zulaica-Hernández, Iker. 2018. A denotation-driven reanalysis of the Spanish neuter pronominal system. Lingua 213: 91-116. 